\title{
Development of environmentally friendly antifouling paints using biodegradable polymer and lower toxic substances
}

\author{
David Carteau ${ }^{\mathrm{a}}$, Karine Vallée-Réhel ${ }^{\mathrm{a}}$, Isabelle Linossier ${ }^{\mathrm{a}}$, Françoise Quiniou ${ }^{\mathrm{b}}$, Romain Davy ${ }^{\mathrm{b}}$, \\ Chantal Compère ${ }^{b}$, Maxime Delbury ${ }^{c}$, Fabienne Fä̈ ${ }^{a}{ }^{a}$
}

\author{
a Laboratoire de Biotechnologie et Chimie Marines (LBCM), UE3884, Université de Bretagne Sud (UBS), \\ Université Européenne de Bretagne (UEB), BP92116,56321 Lorient Cedex, France \\ ${ }^{\mathrm{b}}$ Ifremer, Service Interfaces \& Capteurs, BP 70, 29280 Plouzané, France \\ ${ }^{c}$ Nautix, ZI des 5 chemins, 56520 Guidel, France \\ *: Corresponding author : Fabienne Faÿ, tel.: +330297874626 ; email address : fabienne.fay@univ-ubs.fr
}

\begin{abstract}
:
The development of new antifouling coatings with respect to the marine environment is actually crucial. The aim of the present work is to concept an erodible paint formulated with biodegradable polyester as binders and which combines two modes of prevention: chemical and physical repelling of biofouling. This system is principally dedicated to disturb durable settlement of microfouling. Each component was chosen according to its specific properties: chlorhexidine is a bisdiguanide antiseptic with antibacterial activity, zinc peroxide is an inorganic precursor of high instable entities which react with seawater to create hydrogen peroxide, Tween 85 is a non ionic surfactant disturbing interactions between colonizing organisms and surface. Obtained results highlighted the interest on mixing such molecules to obtain a promising coating with lower toxicity than traditional systems.

\section{Highlights}

Lower toxic antifouling paints, containing substance triggering microfouling, have been developed.

Biodegradable polymer and antimicrofouling substances based paints shows promishing antifouling properties in field tests. This paint is lower toxic than traditional biocidal paints.
\end{abstract}

Keywords: Environmental coatings ; Antifouling ; Active substances ; Microfouling

\section{Introduction}

Marine biofouling can be defined as the undesirable accumulation of microorganisms, algae and invertebrates on submerged unprotected substrates. Fouling causes severe problems on both dynamic and static structures (speed reduction of vessels, increase of fuel consumption, increase of hull maintenance etc.). Over the long history of fouling prevention a variety of methods have been used (tar, pitch, copper sheathing etc.) [1] and [2]. The first antifouling paints appeared in the mild 19th century, containing copper, arsenic or mercury oxide as toxicants dispersed in linseed oil or shellac. However, the most successful antifouling paints in term of long time efficiency have been tributyltin (TBT)-based antifouling paints. Due to environmental concern, these TBT-based systems have been totally banned since 1st January 2008. During the last decade, modern antifouling alternatives consist of coatings containing polymer matrix (acrylic and vinyl resins sometimes blended with rosin) and various kinds of biocides which come into contact with 
fouling organisms [3]. They include organic molecules called booster biocides and mineral compounds such as cuprous oxide and, less commonly, cuprous thiocyanate. Booster biocides are generally toxic against aquatic plants and animals [3,4]. It has long been widely used as algaecides, bactericides and fungicides. Bao and al. suggest that some of these biocides could even be more toxic than tributyltin oxide (TBTO) to certain biota (cyanobacteria, diatoms)[5]. For example, Irgarol, zinc pyrithione and copper pyrithione were more toxic than TBTO on the growth of the two cyanobacteria Chroococcus minor and Synechoccus sp., the diatoms Thalassiosira pseudonana. Mineral copper was relatively less toxic, however the risk of copper toxicity on the marine ecosystem should not be neglected $[3,5,6]$. Toxicity of current anti-fouling paints is largely highlighted $[7,8]$. Hence, there is a real need to develop non-toxic technologies [9].

Non-toxic antifouling strategies include both physical and chemical concepts [10]. Recent research has focused on non-release coatings [11-13]. These approaches are mainly based on controlling physicochemical and mechanical properties such as surface roughness, the elastic modulus, the topographies or the wettability of the surface, which impact on the interactions between marine organisms and the surface [14]. Another antifouling strategy would be to develop formula based on novel biocides (Medetomidine and Econea) or on natural compounds $[4,9,15]$. For example, rosin-based coatings loaded with low concentrations of ivermectin, a macrocyclic lactone, were found to be effective in preventing colonization by barnacles [16]. Green antifouling compounds from microorganisms, seaweeds and aquatic plants, marine invertebrates and from terrestrial natural products have been extensively investigated [17]. Nevertheless, their use into commercial paints is rather slow because the issue of supply has always been a major obstacle [18]. Moreover, paints must reach and maintain a sufficient 
concentration of the active ingredients to give the desired effect. So, an optimization of formulations and biocide release profiles is essential. For example, Bellotti et al. have shown that antifouling paints with zinc "tannate" are promising, nevertheless, antifouling efficiency was dependent on the formulation: the matrix and the plasticizer employed modified the antifouling activity [19].

A critical parameter to control the release of active ingredients and antifouling efficiency concerns the paint erosion. Erosion can be controlled by the nature of the binder [20-21]. So, polyacrylic resins bearing hydrolysable functions have been developed as tin-free alternatives paints. The nature of hydrolysable pendant groups is variable: copper-, zinc-, trialkylsilyl-, trialkyltitanate, ammonium salt or poly(acide lactic) [21-26]. In our research group, biodegradable polymers (polyesters based on polycaprolactone) have been investigated as a potential binder to obtain controlled depletion paints (CDP) [20,27]. Results have shown that $\operatorname{poly}(\varepsilon$-caprolactone-co- $\delta$-valerolactone $(\mathrm{P}(\mathrm{CL}-\mathrm{VL}))$ are good candidates to obtain CDPs taking into account industrial constraints (life-time, stability, biocide release...).

This present study focuses on the use of $\mathrm{P}(\mathrm{CL}-\mathrm{VL})$ as a biodegradable binder combined with no conventional biocides currently used in antifouling paint. Three actives substances are chosen to produce a biodegradable coating combining chemical and physical action and targeting the microfouling. Chlorhexidine, an antibacterial compound, which is used in dentistry as an antidental plaque agent [28-29]. Zinc peroxide $\left(\mathrm{ZnO}_{2}\right)$ is a deterrent that can cause damage to cells and is commonly used for disinfection [30-32]. Detergents such as Tween (polyethylene glycol sorbitan trioleate) (Tween 85) are able to disturb interactions between colonizing organisms and the surface, to decrease bacterial adherence and to favour their release under flow stress. In a previous study, we have highlighted the additive action of three active substances incorporated in 
polyacrylic paint [33]. No synergistic effect between chlorhexidine, tween 85 and zinc peroxide has been observed, nevertheless an interesting antifouling activity has been observed by blending the three molecules and by combining the chemical and physical effects. So, the aims of this study are : i) to evaluate the efficiency of these active substances incorporated into polyester matrix, to concept a new biodegradable coating, ii) the study of its biodegradation, iii) the evaluation of its efficiency against -micro and -macrofouling. Indeed, antifouling efficiency (biological activity, lixiviation) and ecotoxicity are parameters which could be greatly impacted by the nature of polymer matrix (polyacrylic versus polyester) and the formulation type (varnish versus paint).

In a first time, the biological activity of varnishes based on biodegradable polyester and active substances against marine micro-organisms and their ecotoxicity are studied. Then, they are incorporated and evaluated in an antifouling paint. A preliminary evaluation of the interest to targeting microfouling for obtain efficient paint will be addressed.

\section{Materials and Methods}

\subsection{Chemical products}

Tween 85 (Polyethylene glycol sorbitan trioleate), chlorhexidine, zinc peroxide, $\varepsilon$-caprolactone $(\mathrm{CL}), \delta$-valerolactone $(\mathrm{VL})$ and tetrabutoxytitane $\mathrm{Ti}(\mathrm{OBu})_{4}$ were purchased from Acros Chemical. They were used as received without further purification. Zinc pyrithione, dichlofluanid and copper thiocyanate were supplied by Nautix Compagny.

\subsection{Binder}


The polyacrylic binder was purchased from ZENECA. It is a blending of acrylic copolymer poly(methyl methacrylate-co-butyl methacrylate) (PMMA-PBMA) with rosin: a mixture of abietic and dehydroabietic acid obtained from the exudation of pine and fir trees.

The biodegradable polymer, poly( $\varepsilon$-caprolactone-co- $\delta$-valerolactone) $80 / 20$ ( $\mathrm{Mn}=25000 \mathrm{~g} / \mathrm{mol}$, polydispersity index $=1,2$ ) was synthesized (Figure 1 ) and validated as a potential binder in previous studies $[20,27]$. The hydrolysable backbone led to a slow hydrolytic degradation of the immersed binder in demineralized water at $20^{\circ} \mathrm{C}$ and to the control of erosion.

\subsection{Formulation of varnishes}

To evaluate the efficiency of actives substances against micro-organisms, varnishes were formulated. They are simplified coatings and are composed only by binder and active substances. Varnishes were prepared from a solution containing $40 \%(\mathrm{w} / \mathrm{w})$ of the $\mathrm{P}(\mathrm{CL}-\mathrm{VL})$ binder, $10 \%(\mathrm{w} / \mathrm{w})$ of the active substance and $50 \%(\mathrm{w} / \mathrm{w})$ of the diluting agent (xylene). A layer of wet film $(200 \mu \mathrm{m}$ thick) was deposited with an automatic film applicator (ASTM D823 Sheen instrument) on a polycarbonate support. Then the specimens were dried at $20^{\circ} \mathrm{C}$ until they achieved a constant weight. An unloaded varnish was used as negative control.

\subsection{Bacterial strains and culture conditions}

The marine bacteria used, are Bacillus (4J6) and Pseudoalteromonas (3J6), which were grown on a rich medium: Marine Broth (Bacto Marine Broth 2216, Difco). It contains (\%) : peptone 0.5, yeast extract $0.1, \mathrm{FeC}_{6} \mathrm{H}_{5} \mathrm{O}_{7} 0.01, \mathrm{NaCl} 1.945, \mathrm{MgCl}_{2} 0.59, \mathrm{Na}_{2} \mathrm{SO}_{4} 0.334, \mathrm{CaCl}_{2} 0.18, \mathrm{KCl}$

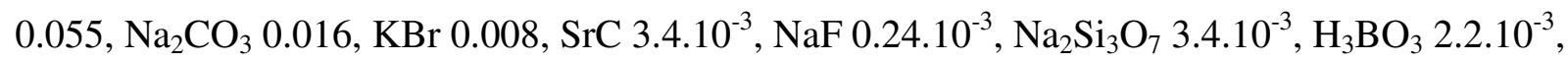
$\mathrm{NH}_{4} \mathrm{NO}_{3} \quad 0.16 .10^{-3}, \mathrm{Na}_{2} \mathrm{HPO}_{4} \quad 0.8 \cdot 10^{-3}$. Planktonic cultures were maintained at $20^{\circ} \mathrm{C}$ whilst shaking. These bacteria were used because they are pioneer adherents. 
Strains were isolated from the surface of a glass cover immersed in natural seawater (Morbihan gulf, France) for 6 hours. Both strains are hydrophilic. 3J6, a Gram negative bacteria, was affiliated to the Pseudoalteromonas genus [34]. Its 16S rDNA sequence (GenBank entry FJ966949) is the most closely related (95.5\% identity) to that of the Pseudoalteromonas sp. SM9913, strain [35] and belongs to a new species. The Gram positive bacteria 4J6 clustered with the genus Bacillus (100\% similarity) [34]. Both bacteria were negatively charged at the $\mathrm{pH}$ of the seawater.

\subsection{Evaluation of antibacterial activities}

The zone of inhibition assay on solid media was used for determination of the antimicrobial effects of varnishes against Pseudoalteromonas $3 \mathrm{~J} 6$ and Bacillus 4J6. $20 \mathrm{~mL}$ of molten MB agar

was inoculated by $1 \mathrm{~mL}$ of bacterial cultures (colony count of $1.10^{7} \mathrm{CFU} / \mathrm{mL}$ ). Coupons of varnishes $(1.5 \times 1.5 \mathrm{~cm})$ were placed on the bacterial carpets and incubated at $20^{\circ} \mathrm{C}$ for $24 \mathrm{~h}$ in an appropriate incubation chamber. The plates were examined, and the diameter of the inhibition zone was measured (in centimeters). These experiments were repeated four times for each sample. The standard deviation was lower than $0.5 \mathrm{~cm}$.

\subsection{Micro-algae strains and culture}

A marine strain Cylindrotheca closterium (Diatomophyceae, AC515) was used. Micro-algae were obtained from the Culture Collection of Algae of the University of Caen (France).

C. closterium was grown in simplified seawater-based culture medium with Guillard's F/2 Marine Enrichment Basal Salt Mixture (Sigma), in sterile conditions at $20^{\circ} \mathrm{C}$ [36]. Artificial seawater was made following Berges et al. [37] and sterilised before use. Guillard's F/2 was added after sterilisation and the culture medium was stored at $4^{\circ} \mathrm{C}$ before use. 
Erlenmeyer flasks were maintained under controlled illumination of $150 \mu$ mol.photons. $\mathrm{m}^{-2} \cdot \mathrm{s}^{-1}$ white fluorescent lamps at $18^{\circ} \mathrm{C}$ with a $16 \mathrm{~h}: 8 \mathrm{~h}$ light:dark cycle. Cultures of C. closterium were initially started with about $3.7 \times 10^{5}$ cell. $\mathrm{mL}^{-1}$.

\subsection{Inhibition of micro-algal growth}

Cultures were exposed to coupons of varnishes $(3 \times 3 \mathrm{~cm})$. After 5, 10 and 15 days, the microalgal density was quantified via Mallassez haemocytometer. All the experiments were carried out three times. The error bars correspond to the average standard deviations.

\subsection{Contact angle measurements}

The procedure has been described previously [33].

\subsection{Active substances eco-toxicity}

The ecotoxicity tests were carried out on five marine organisms. All tests were based on normalized protocols (noted in brackets):

- $\quad$ Phaedactylum tricornum (CCAP 1052/1A) is a planktonic micro-algae (AFNOR, NF EN ISO 10253 (2006)) [38]

- $\quad$ Acartia tonsa is a marine copepod (AFNOR FD ISO 1444669 (2003)) [39]

- $\quad$ Crassostrea gigas is a mollusc bivalve (AFNOR XP T90-382 (2009)) [40]

- $\quad$ Paracentrotus lividus is an echinoderme (ASTM (1995)) [41]

- $\quad$ Dicentrarchus labrax is an European seabass (AFNOR T90-307 (1985)) [42]

The $\mathrm{EC}_{10}$ (no observed effect concentration) and $\mathrm{EC}_{50}$ (effective concentration that causes a $50 \%$ inhibition in the population) values were obtained using Regtox or Pri-Probit software. 


\subsection{Formulation of paints}

Paints were formulated by incorporation of binder, active substances, pigments and additives.

Paint A was supplied by Nautix. It is a commercial paint called A4Tspeed. It will be used as a positive control.

Paints $\mathrm{B}$ and $\mathrm{C}$ were formulated by dispersing all the ingredients (Table 1) under mechanical vigorous agitation $(2000 \mathrm{rpm})$ for $1 \mathrm{~h}$. Then the paints were filtered through a sifter $(100 \mu \mathrm{m})$.

\subsection{Biodegradation test in compost}

The biodegradation is estimated from aerobic degradation of polymer in soil at $58^{\circ} \mathrm{C}$. Biodegradation tests were conducted from Sturm tests according to the EN 13432 [43] and NFU 52001 standard [44]. It was performed in triplicate for each film. The principle is the volumetric titration of the $\mathrm{CO}_{2}$ released by the respiration of the microorganisms present in the soil using the available carbon as a nutrient.

The released $\mathrm{CO}_{2}$ is injected into a $\mathrm{NaOH}$ solution of known concentration and $\mathrm{Na}_{2} \mathrm{CO}_{3}$ is formed, following the equation (1).

$\mathrm{CO}_{2}+2 \mathrm{NaOH}>\mathrm{Na}_{2} \mathrm{CO}_{3}+\mathrm{H}_{2} \mathrm{O}$

$\mathrm{Na}_{2} \mathrm{CO}_{3}$ is precipitated in a solution with an excess of $\mathrm{BaCl}_{2}$, following the equation (2)

$\mathrm{Na}_{2} \mathrm{CO}_{3}+\mathrm{BaCl}_{2}>2 \mathrm{NaCl}+\mathrm{BaCO}_{3}$

The excess of $\mathrm{NaOH}$ is finally measured by $\mathrm{HCl}$ titration in the presence of thymolphtaleine as a colorimetric indicator.

Toxicity test have been carried out on this medium. The percentage of inhibition was calculated as following (3):

inhibition $\%=\frac{\% \mathrm{CO}_{2} \text { release by sample paint }}{\% \mathrm{CO}_{2} \text { release by control }}$ 


\subsection{Evaluation of the efficiency of paints against microfouling}

Paints were applied on polycarbonate panels $\left(50 \mathrm{~cm}^{2}\right)$ using an automatic film applicator (Sheen 1127). The wet films were $200 \mu \mathrm{m}$ thick. Polycarbonate panels are first stuck onto a support. They were then immersed in seawater in March 2011 (Kernevel Harbour, Larmor Plage, France) as described in Faÿ et al. [45]. Coupons were sampled after 5 weeks and observed by Confocal Laser Scanning Microscopy on a Leica TCS-SP 2 microscope using the oil immersion $x 40$ objective. Adherent cells on coatings were stained by adding Syto $61 \mathrm{red} / \mathrm{sytox}$ green stains (5 $\mu \mathrm{M})$ (Molecular Probes), which are fluorescence-based assays for cell viability. Syto 61 red was used as described above and observed in red fluorescence. Sytox ${ }^{\circledR}$ Green nucleic acid stain $(0.5$ $\mu \mathrm{M})$ easily penetrates only cells with compromised plasma membranes. The nucleic acids of dead cells fluoresce bright green when excited with the $488 \mathrm{~nm}$ spectral line of the argon-ion laser $(\lambda$ emission $=500-570 \mathrm{~nm}$, green fluorescence $)$. The biovolume $\left(\mu \mathrm{m}^{3} / \mu \mathrm{m}^{2}\right)$ and average thickness $(\mu \mathrm{m})$ were measured using COMSTAT software [46]. Results are representative of 5 observation sites.

\subsection{Efficiency of paints against macrofouling}

Paint formulations were applied onto panels $(10 \times 10 \mathrm{~cm})$. The marine coating systems have been exposed to sea water for 6 months (from April to September 2011) in the Atlantic Ocean (Kernevel Harbour, France). Duplicate panels were immersed at a depth of $50 \mathrm{~cm}$. The commercial paint (Paint A) was used as a positive control. Non-biocidal paint (Paint B) was used as negative control. Samples were rinsed with seawater just before visual observation, in order to remove unattached species. 


\subsection{Lixiviation test}

Paints (density of 1.3) were applied on polycarbonate panels $\left(164 \mathrm{~cm}^{2}\right)$ using an automatic film applicator (Sheen 1127). The dried films were $100 \mu \mathrm{m}$ thick.

Lixiviation tests were conducted according to a normalised protocol (AFNOR, NF ISO15181) [47]. Immersion and test procedures were carried out as previously described [48]. Water was analysed at each sampling dates and changes in order to risk of medium saturation. Sampling dates were chosen in reference to the standard: 1, 3, 7, 10, 14, 21, 28, 31, 35, 42 and 45 days.

The calculation of the cumulative release rate $\left(\mu \mathrm{g} / \mathrm{cm}^{2}\right)$ after 14 days is made according to the following formula (4) :

$\mathrm{R}_{14}=2 \mathrm{R}_{1}+3 \mathrm{R}_{3}+3.5 \mathrm{R}_{7}+3.5 \mathrm{R}_{10}+2 \mathrm{R}_{14}$

The average release rate corresponds to the average of the release rates determined between 21 and 45 days.

The release of zinc peroxide and chlorhexidine have been quantified by ICP-MS and HPLC-MS respectively.

Chlorhexidine extraction. Before analysis, chlorhexidine has been extracted by SPE extraction (Aspec, Gilson). SDB cartridges $6 \mathrm{~mL}$ (200mg) containing (poly(divinylbenzene-co-Nvinylpyrrolidone)) (JT Baker) were used. The $6 \mathrm{~mL}$ cartridges were first equilibrated with $6 \mathrm{~mL}$ of methanol (3 $\mathrm{mL} / \mathrm{min})$, then $6 \mathrm{~mL}$ ultrapure water $(3 \mathrm{~mL} / \mathrm{min})$. The filtered sample $(200 \mathrm{~mL})$ was then mixed with $200 \mathrm{~mL}$ of ultrapure water and $450 \mu \mathrm{L}$ of $4 \mathrm{M} \mathrm{HCl}(\mathrm{pH} 2.5)$ and $150 \mathrm{~mL}$ was extracted by vaccum aspiration through the SPE cartridge at a flow rate of $10 \mathrm{~mL} / \mathrm{min}$. Then the cardridge washed with $4 \mathrm{~mL}$ of ultrapure water. Chlorhexidine was eluted from the cartridge using $6 \mathrm{~mL}$ of methanol with $1 \% \mathrm{HCl}$ at $1 \mathrm{~mL} / \mathrm{min}$. Samples were collected. $500 \mu \mathrm{L}$ was sampled and diluted (1:1) with ultrapure water containing $1 \% \mathrm{HCl} 4 \mathrm{M}$.

HPLC-MS-MS. The release of chlorhexidine has been quantified by HPLC-MS-MS (UPLC Acquity, Waters) equipped with an ESI source and a triple quadrupole mass spectrometer (Quatro Micro, Micromass) : 
- Mobile phase A : ultrapure water $+1 \%$ methanol $+0.05 \%$ trifluoroacetic acid

- Mobile phase B : acetonitrile $+0.05 \%$ trifluoroacetic acid.

- Gradient :
○ 0 min
$15 \%$ Eluent B
○ $4.5 \mathrm{~min}$
$22.5 \%$ Eluent B
○ $\quad 5-7 \mathrm{~min}$
$50 \%$ Eluent B
○ $\quad 8-10 \mathrm{~min}$
$15 \%$ Eluent B

- Elution at $0.4 \mathrm{~mL} / \mathrm{min}$

- Column : C18

- Injected volume : $7 \mu \mathrm{L}$ (Partial Loop With Needle Overfill)

- Column temperature : $45^{\circ} \mathrm{C}$

- Detection: For MS scanning in positive mode, argon was used as the drying $\left(360^{\circ} \mathrm{C}, 650\right.$ L/hours) and nebulizer (from 3 to $3.5 .10^{-3}$ mbar).

Stock standard solutions of chlorhexidine were prepared ultrapure in water/methanol (1:1) containing $1 \% \mathrm{HCl} 4 \mathrm{M}$ at a concentration of $0.5 \mathrm{~g} / \mathrm{L}$ and stored at $-18^{\circ} \mathrm{C}$. The calibration standard were prepared at concentration of $50,100,200,500,1000,2000 \mu \mathrm{g} / \mathrm{L}$ of chlorhexidine and stored at $4^{\circ} \mathrm{C}$.

ICP-MS. Samplings $(100 \mathrm{~mL})$ were acidified with a solution of nitric acid $(70 \%)(1 \mathrm{~mL})$ to dissolve all degradation products. The spectrometer was an ICP 820 MS Varian. The solution is pumped by a peristaltic pump and the nebulizer is of the Seaspray type. The aerosol produced is directed into a quartz plasma torch.

The standard curve were realized with two calibration standards $(0.1$ and $1 \mathrm{mg} / \mathrm{L})$ in nitric acid $0.7 \%$. The zinc standard solution $(1 \mathrm{~g} / \mathrm{L})$ was furnished by Varian.

\subsection{Statistical analysis}

Statistical analysis of the data was done with Matlab 7.4. P values were calculated by analysis of variance. $\mathrm{P}$ values of $<0.05$ were considered significant. Error bars represent confidence intervals with a confidence level of $95 \%$. 


\section{Results and Discussion}

The objectives of the present study are to develop and evaluate a new antifouling paint containing biodegradable polymer and three specific active substances. The approach used is to evaluate the efficiency and environmental impact of these substances. Then antifouling paint was formulated and evaluated in term of biodegradability and efficiency (against micro- and macrofouling).

\subsection{Evaluation of active substances}

Active substances were studied in vitro to i) confirm their biological activity after incorporation in a polyester-based varnish, and ii) to quantify their ecotoxicity against five trophic level.

\section{$\underline{\text { 3.1.1 Biological activity }}$}

Previous study has shown that selected molecules show a potential activity against the settlement of micro-organisms [33]. Tween 85 is an advantageous antifouling compound acting by a physical approach and without toxicity. The modification of surface properties by Tween 85 , led to an increase of hydrophilic surface, decreasing the absorption of conditioning film and thereby reduces the adhesion of micro-organisms [33,48-50]. Chlorhexidine has shown a high activity against marine bacteria and microalgae by chemical action. Zinc peroxide acts by oxidative action on organisms: an anti-micro-algal effect was observed.

Varnishes containing active substances or traditional biocides were tested against two marine bacteria to confirm biological activity : Bacillus $4 \mathrm{~J} 6$ and Pseudoalteromonas 3J6 and a microalgae Cylindrotheca Closterium (Figures 2 and 3). Figure 2 shows the diameter of inhibition spot around varnishes. It appears that the growth of both bacteria was affected by dichlofluanid<zinc pyrithione=chlorhexidine. In contrary, no inhibition was observed for Tween 85 , zinc peroxide 
and copper thiocyanate. The effect of varnishes on the growth of C. Closterium was observed over 5, 10 and 15 days (Figure 3). The graph plots the mean cell concentration for each varnish and shows that cell failed to growth for varnishes containing zinc pyrithione, dichlofluanid, chlorhexidine or zinc peroxide. According to these observations, the chemical action of chlorhexidine and zinc peroxyde has been confirmed after incorporation in $\mathrm{P}(\mathrm{CL}-\mathrm{VL})$ film. Tween 85 shows no chemical activity, whereas a modification of Tween 85-based varnish surface properties was observed by increasing the surface hydrophily: the angle contact of water decreases from $95.4^{\circ}$ to $57.8^{\circ}$ for unloaded and loaded varnishes respectively. This hydrophilic character of Tween-85 based varnish slightly increases during the immersion time: after one week the contact angle reaches a stable value of $53.2^{\circ}$ (results not shown) which is significantly

more lower $(\mathrm{p}<0.05)$ than unloaded varnish $\left(92.2^{\circ}\right)$. Moreover, as for polyacrylic-based varnishes [33], polyester-based varnished trended to be more electron donating in the presence of Tween $85\left(\gamma_{-}=14.2>\gamma_{+}=4.2\right)$. So, a physical repelling of Tween 85 can be confirmed.

\subsubsection{Active substances toxicity}

Active substances have been evaluated for their toxicity following normalized protocols. Five trophic levels have been studied: one phytoplankton (Phaedactylum tricornutum), three invertebrates (Acartia tonsa, Crassostrea gigas and Paracentrotus lividus) and one vertebrate (Dicentrarchus labrax). $\mathrm{EC}_{10}$ and $\mathrm{EC}_{50}$ of substances towards marine organisms are listed in Table 2. To better protect the environmental medium, the lower $\mathrm{EC}_{50}$ or $\mathrm{EC}_{10}$ value was retained to rank the molecules.

Results indicate that all substances affect organisms tested. Conventional biocides (copper thiocyanate, dichlofluanid and zinc pyrithione) show a high toxicity towards the five trophic 
levels. As already shown in several studies, zinc pyrithione was found to be more toxic than the other traditional biocides [51]. Dichlofluanid had relatively low toxicity compared to other biocides such as TBT, diuron or Irgarol 1051 [52]. For copper thiocyanate, the three most sensitive species are the embryo/larvae of the oyster, mussel and sea urchins [53]. Contrariwise, the active substances studied in this paper show relatively lower toxicity against marine organisms:

- Tween 85 can be considered as non-toxic because the $\mathrm{EC}_{50}$ was higher than $1000 \mu \mathrm{g} / \mathrm{L}$ for all species.

- Zinc peroxide is a strong oxidizing agent which can be toxic against microalgal organisms. Results for zinc peroxide show toxicity towards bivalves essentially. $\mathrm{EC}_{10}$ was equal to $46.8 \mu \mathrm{g} / \mathrm{L}$ which is close to results observed with copper thiocyanate, dichlofluanid and zinc pyrithione. Nevertheless, a lower toxicity was observed for the other marine organisms.

- Chlorhexidine shows a high impact for only two species. It acts on the growth of Phaedactylum tricornutum and the mortality of Paracentrotus lividus.

Substances were ranked versus their toxicity. The comparison of $\mathrm{EC}_{50}$ and $\mathrm{EC}_{10}$ values allows the following ranking: zinc pyrithione $>$ chlorhexidine $=$ copper thiocyanate $>$ dichlofluanid $>$ zinc peroxide $>$ Tween 85 . Hence, zinc peroxide and Tween 85 show a lower toxicity than traditional biocides. Toxicity of chlorhexidine is close to copper thiocyanate, nevertheless, it is a molecule largely used in biomedical and cosmetic applications.

Hence, toxicity tests and activity tests against microfouling have shown potential interest of these three selected molecules. They combine activity against microfouling and lower toxicity than traditional biocide.

\subsection{Evaluation of binder}


The binder structure has been selected from previous works which have shown that poly $(\varepsilon-$ caprolactone-co- $\delta$-valerolactone), with $80 \%$ and $20 \%$ of hydroxycaproïc and hydroxypentanoïc units respectively, was a good candidate as a binder in antifouling paint [20,27]. This polymer has previously been used in biomedical applications as an implantable matrix for a drug delivery system, which controls the release over a relatively long period of time [53]. Recently, it has been investigated as biodegradable impact modifiers for poly(lactic acid) (PLA) in order to enhance the low brittleness of polylactide [54]. Nevertheless, no published study has investigated the biodegradation of this polymer. This is the reason why, the biodegradation kinetics of the $\mathrm{P}(\mathrm{CL}-\mathrm{VL})$ was evaluated according to the normalized test (EN 13431) [43]. As shown in Figure 4, $\mathrm{P}(\mathrm{CL}-\mathrm{VL})$ is almost completely biodegraded after 40 days. So, $\mathrm{P}(\mathrm{CL}-\mathrm{VL})$ could be considered as biodegradable polymer. A similar tendency was observed for poly( $\varepsilon$-caprolactone) (PCL) by other researchers [55-57]. In other hand, several authors have shown that the specific conditions of the seawater environment are favourable for the (bio)degradation of polyester films, such as PCL $[56,58,59]$. So, we can suppose that biodegradation will occur on P(CL-VL) films in seawater.

\subsection{Evaluation of paint based on biodegradable binder and active substances}

Previous results have highlighted the interest on mixing the selected molecules (chlorhexidine, Tween 85 and zinc peroxide) to get additive action on antifouling efficiency [33]. The following experiments aimed to evaluate if a paint based on these ingredients (biodegradable binder and selected molecules blended) can perform as well as a traditional biocidal paint in term of efficiency but with a lower environmental impact. For this purpose, a paint (called paint C) was formulated with biodegradable binder and active substances. The lixiviation of active 
molecules, the paint biodegradability and the efficiency against micro- and macro-fouling were evaluated versus reference paints.

\subsubsection{Lixiviation of active molecules}

Active substances have been evaluated for their lixiviation following normalized protocols. Tween 85 was not quantified because this compound could not be assayed. The total amount of zinc peroxide and chlorhexidine from panels during immersion for 45 days in artificial seawater was determined. Figure 5 show cumulative release of substances during immersion. Chlorhexidine is released faster and in greater amounts than zinc peroxide. These observations can be explained by their different solubilites: chlorhexidine is more soluble in water $(800 \mathrm{mg} / \mathrm{L}$ at $\left.20^{\circ} \mathrm{C}\right)$ than zinc peroxide $\left(5 \mathrm{mg} / \mathrm{L}\right.$ at $\left.20^{\circ} \mathrm{C}\right)$. The cumulative amount release after 14 days was found to be $178 \mu \mathrm{g} / \mathrm{cm}^{2}$ and $212 \mu \mathrm{g} / \mathrm{cm}^{2}$, which correspond to $10 \%$ and $27 \%$ of release for zinc peroxide and chlorhexidine respectively. After 21 days of immersion, a lower leaching of chlorhexidine is observed, whereas a progressive leaching is obtained for zinc peroxide. Between 21 and 45 days, the average release rate of $7 \mu \mathrm{g} / \mathrm{cm}^{2} /$ day for zinc peroxide and $2 \mu \mathrm{g} / \mathrm{cm}^{2} /$ day for chlorhexidine were obtained, representing $19 \%$ and $37 \%$ of zinc peroxide and chlorhexidine released after 45 days of immersion. These values are typical for an erodible paint: the active molecules were rapidly release of the paint, then a very low amount of molecules was observed (near to the limit of detection) [16;48].

\subsubsection{Coating biodegradability}

Biodegradability of the new coating based on biodegradable polymer and active substances (paint C) has been compared with a commercial paint (called paint A). Paint A and paint $\mathrm{C}$ were 
tested and compared with biopolymer cellulose, known to be totally biodegradable. Paints were incubated in the presence of micro-organisms following normalized protocol. The release of $\mathrm{CO}_{2}$ was monitored versus time (Figure 6a). It indicates a typical release of $\mathrm{CO}_{2}$ for biodegradable cellulose whereas paint $\mathrm{A}$ and $\mathrm{C}$ show an inhibitor effect: the $\mathrm{CO}_{2}$ release decreases versus time. This result indicates an inhibition of micro-organisms by paints. So, biodegradability test can't be carried out, nevertheless results give indications about paints toxicity. Figure $6 \mathrm{~b}$ clearly shows that paint A strongly inhibits micro-organisms with a sterilisation of medium. Contrariwise, micro-organism inhibition for paint $\mathrm{C}$ is relatively low (lower to $20 \%$ ) and rapidly decreases with time. These results confirm that active substances included in the paint would be less toxic than traditional biocides because a decrease of inhibitor effect has been demonstrated.

\section{$\underline{\text { 3.3.3 Antifouling activity of paints }}$}

Coatings were immersed on a raft to evaluate the in vivo efficiency of coatings. The experiment involved coatings immerses at $50 \mathrm{~cm}$ depth in Kernevel harbor. Efficiency of paints was evaluated i) by the quantification of microfouling adhered after 5 weeks of immersion (determined by confocal laser scanning microscopy after staining); ii) by visual inspection of macrofouling developed onto coatings after six months of immersion. Paint $\mathrm{C}$ was compared with commercial paint $\mathrm{A}$ and paint without biocide (called paint B) as positive and negative controls in term of efficiency.

Results of anti-microfouling activity during the first weeks of immersion are shown in Figure 7 and Table 3. Micrographies and bioadhesion analysis revealed that paint $\mathrm{C}$ was efficient against 
microfouling. The biomass and average thickness developed on paint $\mathrm{C}$ is significantly $(\mathrm{p}<0.05)$ lower than paint B and close to paint A (Table 3).

After 5 weeks in natural seawater, reference paint (paint A) revealed a homogeneous biofilm. It was totally covered by diatoms and the adhered biomass and average thickness were relatively low. Contrariwise, the development of homogeneous and thicker fouling films on negative control (paint B) was mainly due to the growth of chains of micro-algae on the surface: a thick and dense biofilm was observed. In the case of the paint $\mathrm{C}$, a heterogeneous structure with bacteria and a few micro-algae was developed, which was contributed to an average thickness relatively heterogeneous $(30.2 \pm 21.1 \mu \mathrm{m})$ but a low biomass.

Results of anti-macrofouling activity are shown in Figure 8. Paint A was used as reference paint representing high antifouling efficiency. Paint B, without biocide, was used as controls to assess which organisms settled on non-effective coating. The main biofouling organisms observed were green algae and encrusting species such as bryozoans, spirorbs worms and barnacles. As seen on the paint $\mathrm{C}$, only slime and few green algae (40 and 15\% coverage percent respectively) were quantified during the six months of immersion.

Results presented in this study clearly showed an antifouling activity (against micro- and macrofouling) of paints based on active substances and biodegradable binder during the first months of immersion. Biocides that are used to control biofouling in antifouling strategies are generally not effective against some bacterial and diatom species. Nevertheless, these are the pioneer colonizers, and they act about the adhesion of superior organisms. So, obtaining antimicrofouling activity could be advantageous for obtain an efficiency for a longer period. 
Hence, it is possible to combine antifouling activity and low environmental impact. Two parameters are combined:

- The use of biodegradable binder which allow obtaining a homogeneous erosion of paint as previously shown [27]. The erosion mechanisms are similar to paints based on polyacrylic and rosin binder.

- $\quad$ The use of three molecules with different modes of action allows eliminating more toxic biocides that are commonly used. A lower concentration of each substance is sufficient to produce antifouling activity and reduce coatings toxicity. This result has already been claimed by Arrhenius et al., which added that this strategy reduced the risk of the development of tolerance by the target organisms [60].

\section{Conclusions}

Three active substances and a biodegradable polymer were investigated in this study as potential alternatives for biocidal antifouling paints. A chemical action of chlorhexidine and zinc peroxide against microfouling (bacteria and/or microalgae) was shown, while physical action of Tween 85 occurred. A lower toxicity for these active substances was revealed comparatively to classical biocides such as zinc pyrithione or copper thiocyanate.

The incorporation of the selected active substances into a paint formulation based on biodegradable binder and the investigation of the paint under real conditions were the second goal of the study. It was found that this new paint presents an activity against micro- and macrofouling for one season.

In conclusion, in the present work it is shown that the use of three active substances in a biodegradable binder: 
- $\quad$ provides antifouling protection against biofouling for several months,

- $\quad$ shows the interest to use substances targeting the microfouling,

- $\quad$ shows that it is possible to obtain antifouling activity with lower toxic substances.

\section{Acknowledgments}

The authors acknowledge the financial support provided by the FCE (Project PAINTCLEAN), and the "Pôle Mer Bretagne and PACA".

\section{References}

1. Chambers, L.D.; Stokes, K.R.; Walsh, F.C.. Wood R.I.K. Surface and Coatings Technology. 201 (2006) 3642-3652.

2. Almeida, E.; Diamantino, T.C.; de Sousa, O. Progress in Organic coatings. 59 (2007) 220.

3. Dafforn, K.A.; Lewis, J.A.; Johnston, E.L. Marine Pollution Bulletin 62 (2011) 453-465.

4. Thomas, K.V.; Brooks, S. Biofouling. 26 ( 2010) 73-88.

5. Bao, V.W.W.; Leung, K.M.Y.; Qiu, J.W.; Lam, M.H.W. Marine Pollution Bulletin. 62 (2011) 1147-1151.

6. Brooks, S.; Waldock, M. The use of copper as a biocide in marine antifouling paints. In: Advances in antifouling coatings and technologies. C. Hellio, D. Yebra, Cambridge: Woodhead Publishing Limited. 2009, pp. 492-521. 
7. Karlsson, J.; Ytreberg, E.; Eklund, B. Environmental Pollution 158 (2010) 681-687.

8. Turner, A. Marine Pollution Bulletin. 60 (2010) 159-171.

9. Maréchal, J.P.; Hellio, C. Int. J. Mol. Sci. 10 (2009) 4623-4637.

10. Magin, C.M.; Cooper, S.P.; Brennan, A.B. Materialstoday. 13 (2010) 36-44.

11. Scardino, A.J.; de Nys, R. Biofouling. 27 (2011) 73-86.

12. Fang, J.; Kelarakis, A.; Wang, D.; Giannelis, E.P.; Finlay, J.A.; Callow, M.E.; Callow, J.A. Polymer 51 (2010) 2636-2642.

13. Glinel, K.; Thebault, P.; Humblot, V.; Pradier, C.M.; Jouenne, T. Acta Biomaterialia. 8 (2012) 1670-1684.

14. Banerjee, I.; Pangule, R.C.; Kane, R.S. Advanced Materials. 23 (2011) 690-718.

15. Pérez, M.C.; Stupak, M.E.; Blustein, G.; Garcia, M. Organic alternatives to copper in the control of marine biofouling In: Advances in antifouling coatings and technologies. C. Hellio, D. Yebra, Cambridge: Woodhead Publishing Limited. 2009, pp. 554-567.

16. Pinori, E.; Berglin, M.; Brive, L.M.; Hulander, M.; Dahlström, M.; Elwing, H. Biofouling 27 (2011) 941-953.

17. Qian, P.E.; Xu, Y.; Fusetani, N. Biofouling. 26 (2010) 223-234.

18. Mendola, D. Biomolec Eng. 23 (2003) 441-458. 
19. Bellotti, N.; Deya, C.; del Amo, B.; Romagnoli, R. Ind. Eng. Chem. Res. 49 (2010) 33863390.

20. Faÿ, F. ; Renard, E.; Linossier, I.; Langlois, V.; Vallée-Réhel, K. European Polymer journal 43 (2007) 4800-4813.

21. Bressy, C.; Margaillan, A. Progress in Organic Coatings. 66 (2009) 400-405.

22. Camail, C.; Humbert, M.; Margaillan, A.; Riondel, A.; Vernet, J.L. Polymer 39 (1998) $6525-6529$.

23. Yonehara, Y.; Yamashita, H.; Kawamura, C.; Itoh, K. Progress in Organic Coatings. 42 (2001) 150-158.

24. Langlois, V.; Vallee-Réhel, K.; Peron, J.J.; Le Borgne, A.; Walls, M.; Guerin, Ph. Polymer Degradation and Stability. 76 (2002) 411-417.

25. Yebra, D.M.; Kiil, S.; Dam-Johansen, K. Progress in Organic Coatings. 50 (2004) 75-104.

26. Nguyen, M.N.; Bressy, C.; Margaillan, A. J Polym Sci Part A Polym Chem. 43 (2005) 56805689.

27. Faÿ, F.; Linossier, I.; Péron, J.J.; Langlois, V.; Vallée-Réhel, K. Progress in Organic Coatings. 60 (2007) 194-206.

28. Cortizo, M.C.; Oberti, T.G.; Cortizo, M.S.; Cortizo, A.N.; Fernandez Lorenzo de Mele, M.A. Journal of dentistry. 40 (2012) 329-337. 
29. Cheng, L.; Weir, M.D.; Xu, H.H.K.; Kraigsley, A.M.; Lin, N.J.; Lin-Gibson, S.; Zhou, X. Dental materials. 28 (2012) 573-583.

30. Olsen, S.M.; Pedersen, L.T.; Hermann, M.H.; Kiil, S.; Dam-Johansen, K. J. Coat. Technol. Research. 6 (2009) 187-199.

31. Olsen, S.M.; Pedersen, L.T.; Dam-Johansen, K.; Kiil, S. Biofouling. 26 (2010) 213-222.

32. Olsen, S.M.. Kristensen, J.B.; Laursen, B.S.; Pedersen, L.T.; Dam-Johansen, K.; Kiil, S. Progress in Organic Coatings. 68 (2010) 248-257.

33. Faÿ, F.; Carteau, D.; Linossier, I.; Delbury, M.; Vallée-Réhel, K. Colloids and Surfaces B: Biointerfaces. 102 (2013) 569-577.

34. Grasland, B.; Mitalane, J.; Briandet, R.; Quemener, E.; Meylheuc, T.; Linossier, I.; ValléeRéhel, K.; Haras, D. Biofouling. 19 (2003) 307-313.

35. Qin, G.; Zhu, L.; Chen, X.; Wand, G.; Zhang, Y. Microbiology. 153 (2007) 1566-1572.

36. Guillard, R.; Ryther, J. Canadian Journal of Microbiology. 8 (1962) 229-239.

37. Berges, J.A.; Franklin, D.J.; Harrison, P.J. J. Phycol. 37 (2001) 1138-145.

38. AFNOR, NF EN ISO 10253 Juin 2006. Qualité de l'eau - Essai d'inhibition de la croissance des algues marines avec Skeletonema costatum et Phaeodactylum tricornutum - T90-311.

39. AFNOR, FD ISO 14669. 2003, Qualité de l'eau - Determination de la toxicité létale aiguë vis-à-vis des copépodes marins (Copépoda, Crustacea) 23p. 
40. AFNOR, XP T90-382 Septembre 2009. Qualité de l'eau - Bio indicateur de la toxicité potentielle de milieux aqueux - Détermination de la toxicité potentielle d'échantillons aqueux sur le développement embryo-larvaire de bivalve - T90-382.

41. ASTM, 1995, Standard guide for conducting static acute tests with Echinoïdes embryos. In ASTM 1995 Annual book of standards, 999-1017. American Society for Testing and Materials, Philadelphia.

42. AFNOR, T90-307 Juin 1985. Essais des eaux - Détermination de la toxicité aigüe d'une substance vis-à-vis de Dicentrarchus labrax - Méthode sans renouvellement du milieu. T90-307.

43. AFNOR, NF EN 13431 Novembre 2000. Emballage - Exigences relatives aux emballages valorisables par compostage et biodégradation - Programme d'essai et critères d'évaluation de l'acceptation finale des emballages - H60-140.

44. AFNOR NF U52-001 Février 2005. Matériaux biodégradables pour l'agriculture et l'horticulture - Produits de paillage - Exigences et méthodes d'essai - U52-001.

45. Faÿ, F.; Carteau, D.; Linossier, I.; Vallée-Réhel, K. Progress in Organic Coatings. 72 (2011) $579-585$.

46. Heydorn, A.; Nielson, A.T.; Hentzer, M.; Sternberg, C.; Givskov, M.; Ersboll, B.K.; Molin, S. Microbiology. 146 (2000) 2395-2407.

47. AFNOR NF EN ISO 15181. Peintures et vernis - Détermination du taux de lixiviation des biocides contenus dans les peintures antisalissures. 
48. Thouvenin, M.; Peron J.J.; Charreteur, C.; Guerin Ph.; Langlois J.Y.; Vallée-Réhel K. Progress In Organic Coatings. 44 (2002) 75-83.

49.Xie, Y.; Yu, H.; Wang, S.; Xu, Z. Journal of Environmental Sciences. 19 (2007) 1461-1465.

50. Cowie, P.R.; Smith, M.J.; Hannah, F.; Cowling, M.J.; Hodgkeiss, T. Biofouling. 22 (2006) 195-207.

51. Lopez-Galindo, C.; Casanueva, J.F.; Nebot, E. Biofouling. 26 (2010) 923-930.

52. Konstantinou, I.K. ; Albanis, T.A. Environment international. 30 (2004) 235-248.

53. Fernandez-Alba, A.R.; Hernando, M.D.; Piedra, L.; Chisti, Y. Analytica Chemica Acta. 456 (2002) 303-312.

54. Imasaka, K.; Yoshida, M.; Fukuzaki, H.; Asano, M.; Kumakura, M.; Mashimo, T.; Yamanaka, H.; Nagai, T. International Journal of Pharmaceutics. 68 (1991) 87-95.

55. Odent, J.; Raquez, J.M.; Duquesne, E.; Dubois Ph. European Polymer Journal. 48 (2012) $331-340$.

56. Rutkowska, M.; Jastrzebska, M.; Janik, H. Reactive \& Functional Polymers. 38 (1998) 2730.

57. Fukushima, K.; Abbate, C.; Tabuani, D.; Gennari, M.; Rizzarelli, P.; Camino G. Materials Science and Engineering C. 30 (2010) 566-574.

58. Yagi, H.; Ninomiya, F.; Funabashi, M.; Kunioka, M. Polymer Degradation and Stability. 94 (2009) 1397-1404. 
59. Tsuji, H.; Suzuyoshi, K. Polymer Degradation and Stability. 75 (2002) 347-355.

60. Arrhenius, A.; Backhaus, T.; Gronvall, F.; Junghans, M.; Scholze, M.; Blanck, H. Arch Environ Contam Toxicol. 50 (2006) 335-345. 


\section{Figures Caption}

Figure 1. Chemical structure of poly( $\varepsilon$-caprolactone-co- $\delta$-valerolactone) $80 / 20$ obtained by ring opening polymerisation

Figure 2. Diameter of inhibition spot around varnishes $(1.5 \times 1.5)$ after 24 hours of incubation

Figure 3. Effect of active substances incorporated in varnishes on growth of Cylindrotheca

\section{Closterium}

Figure 4. Biodegradation respirometric tests according to EN 13432 for $\mathrm{P}(\mathrm{CL}-\mathrm{VL})$ 80/20 (compared with cellulose as control)

Figure 5. Release of chlorhexidine and zinc peroxide from paint $\mathrm{C}$.

Figure 6. Biodegradation respirometric tests according to EN 13432 for paints A and C. A) $\mathrm{CO}_{2}$ release versus time ; B) inhibitor effect of paints in compost versus time

Figure 7. CLSM photography of microfouling on antifouling paint after 5 weeks of immersion in natural seawater. A. Paint A; B. Paint B; C. Paint C

Figure 8. Photographs of panels immersed in sea water environment 
Figure 1.

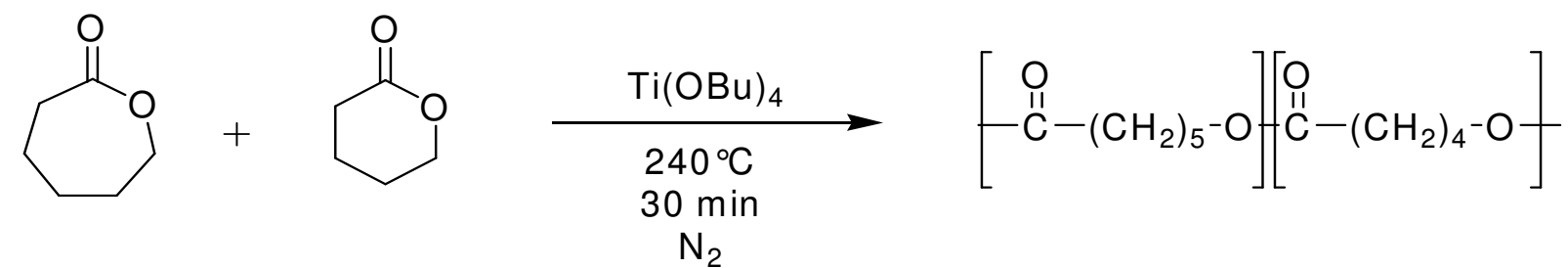


Figure 2.

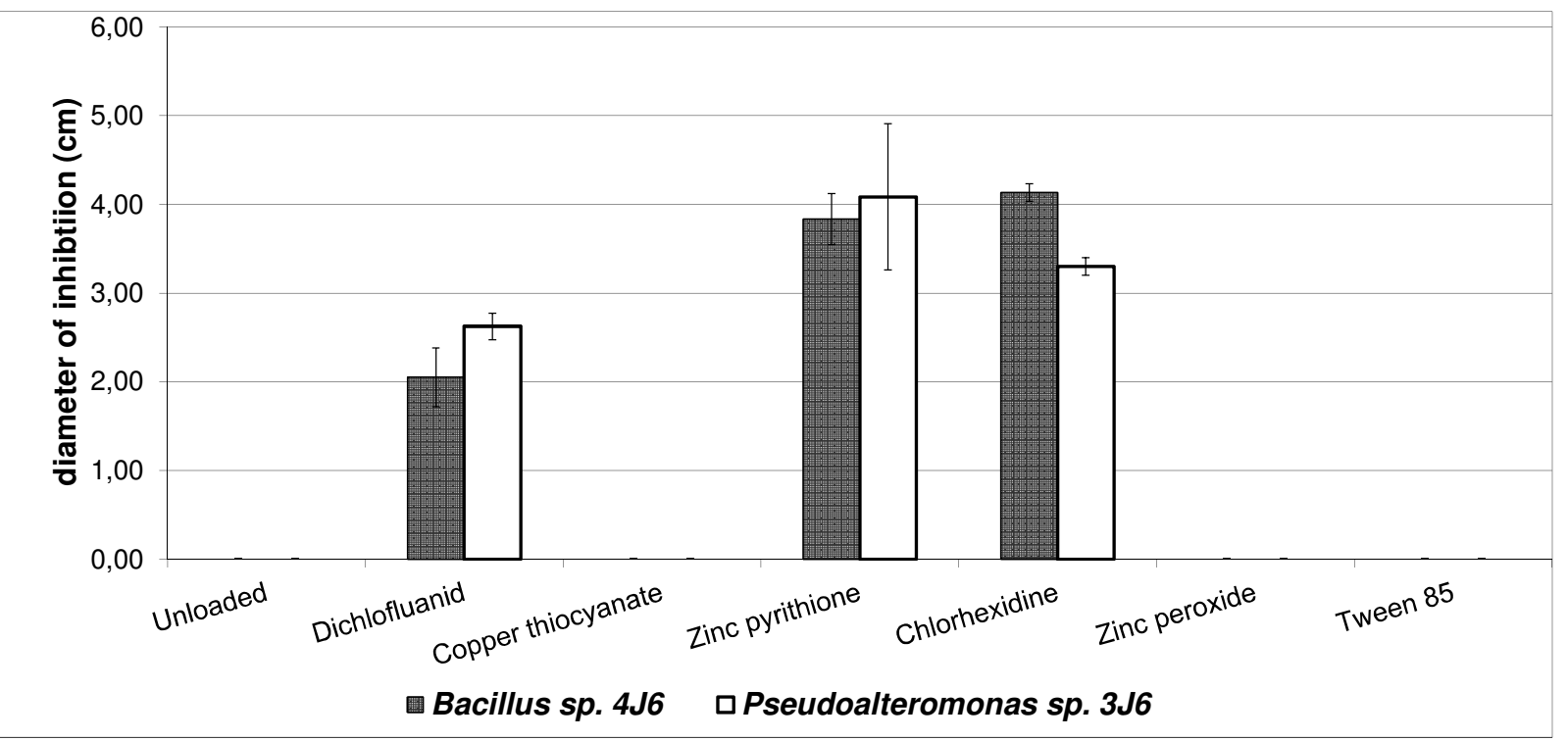


Figure 3.

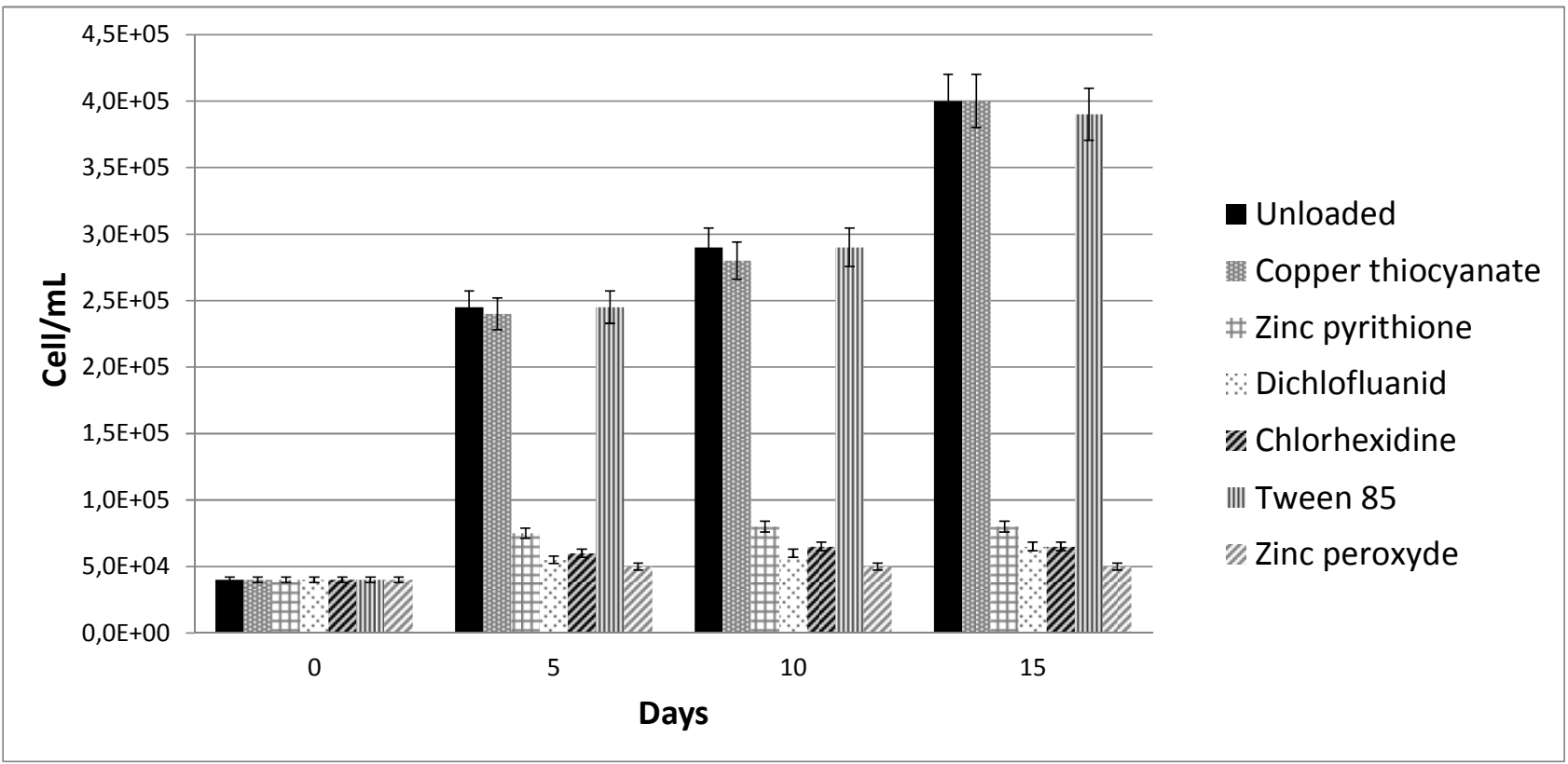


Figure 4.

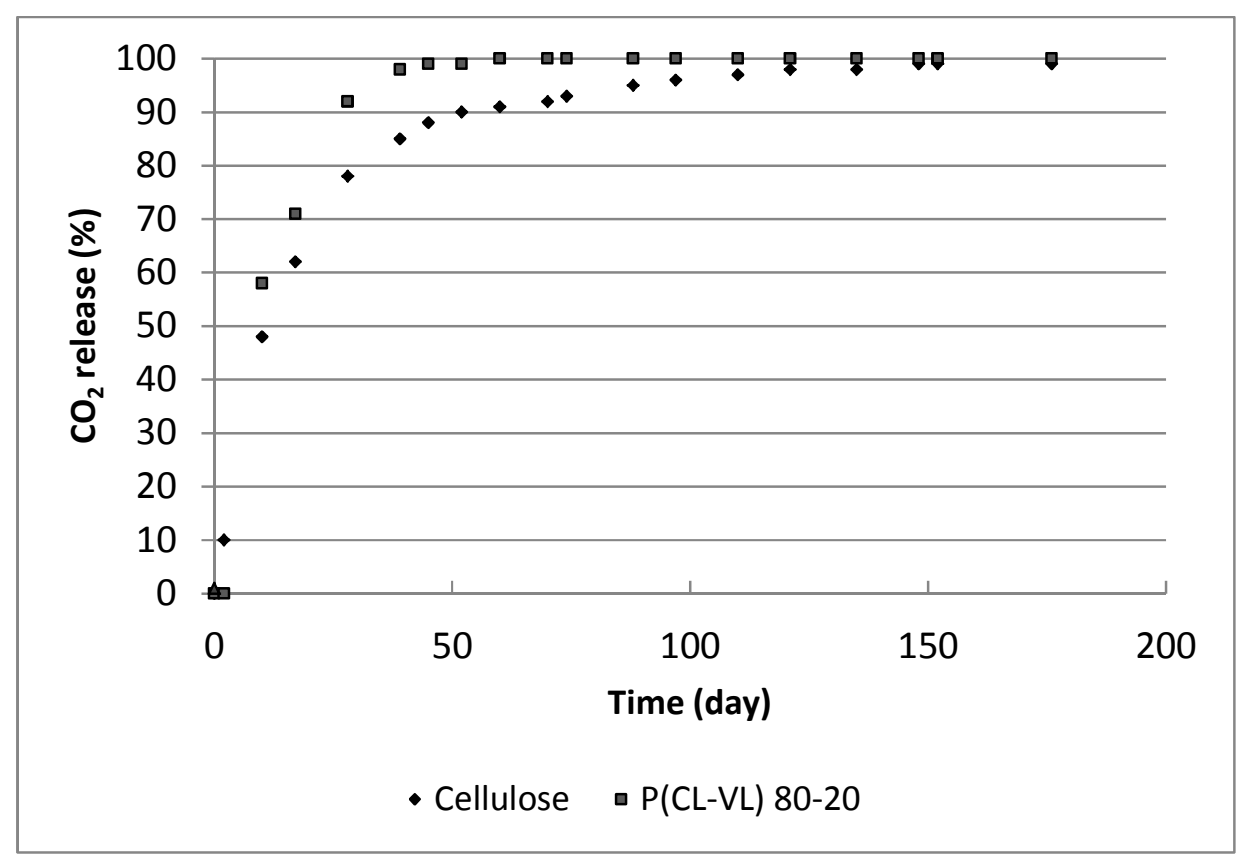


Figure 5.

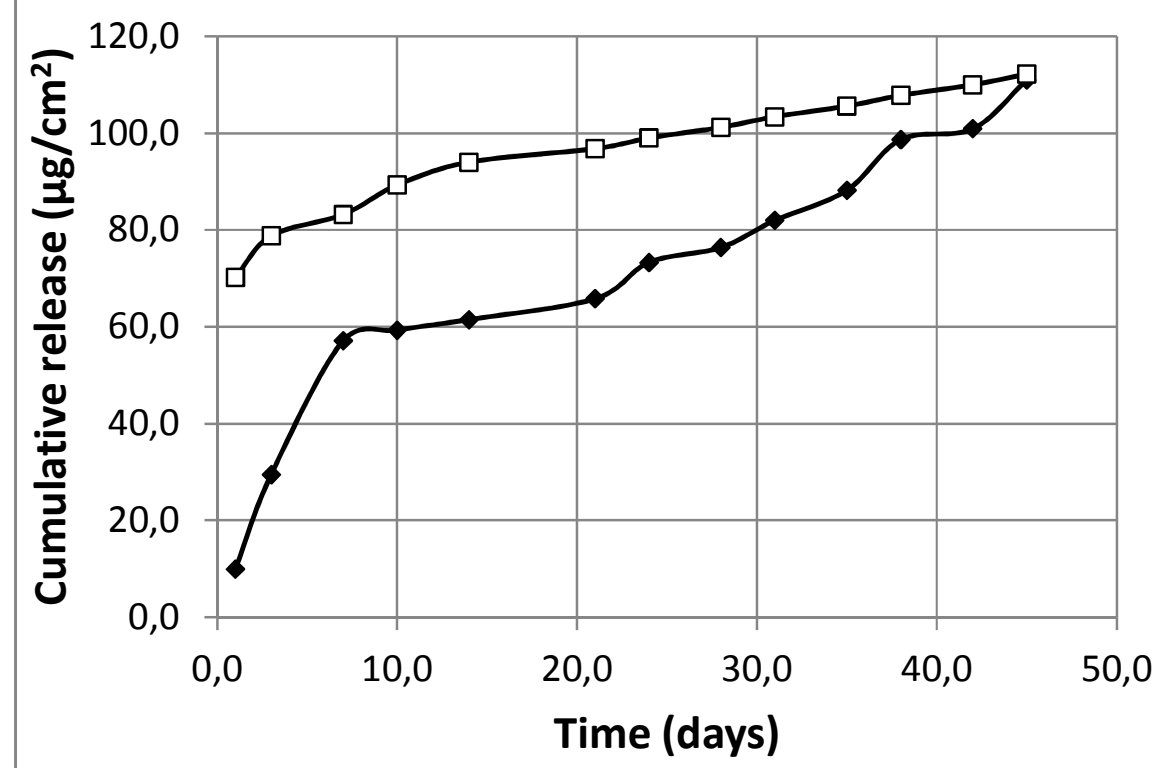

$\rightarrow-$ Zinc peroxide $\quad \rightarrow-$ Chlorhexidine 
Figure 6.
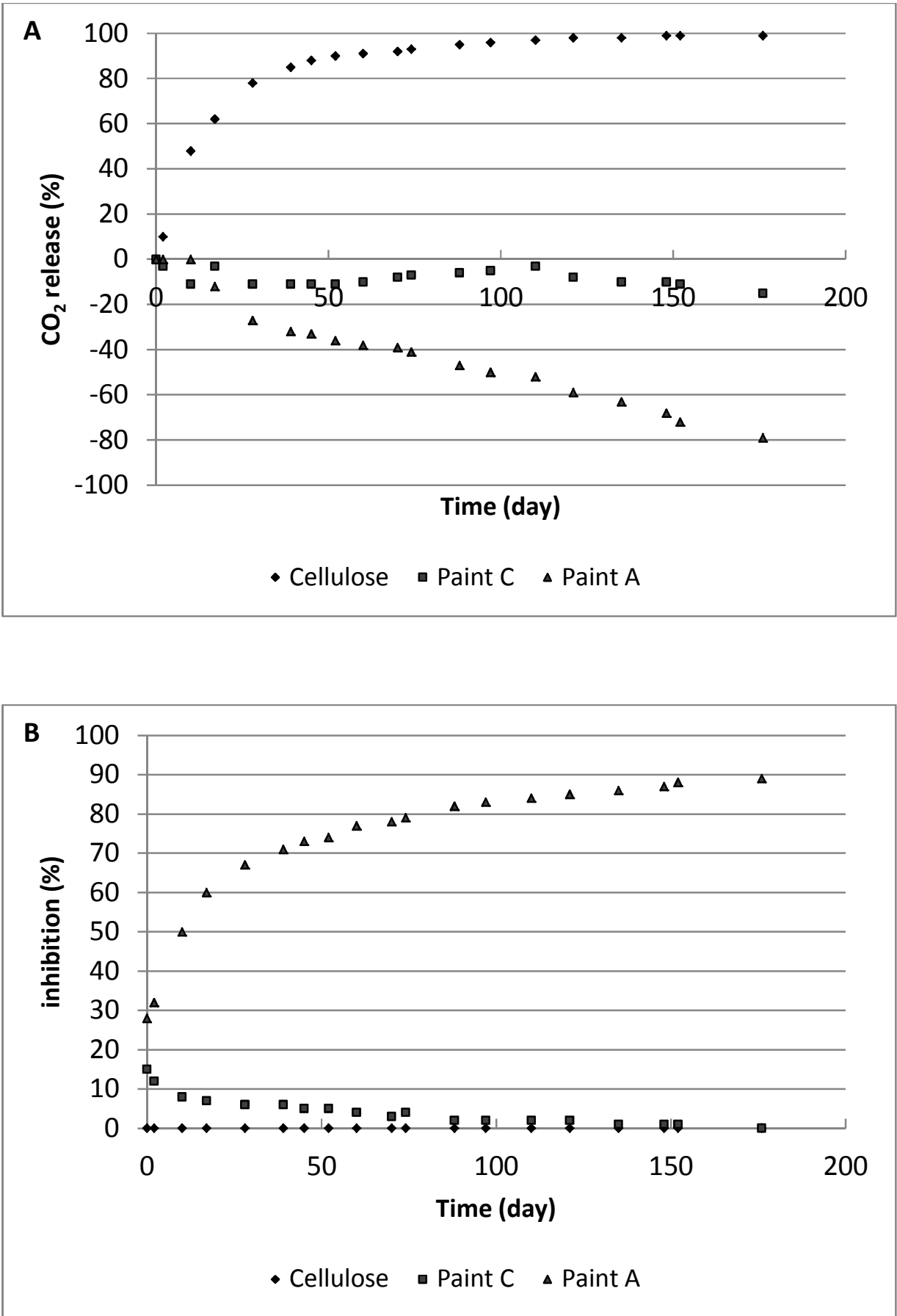
Figure 7.

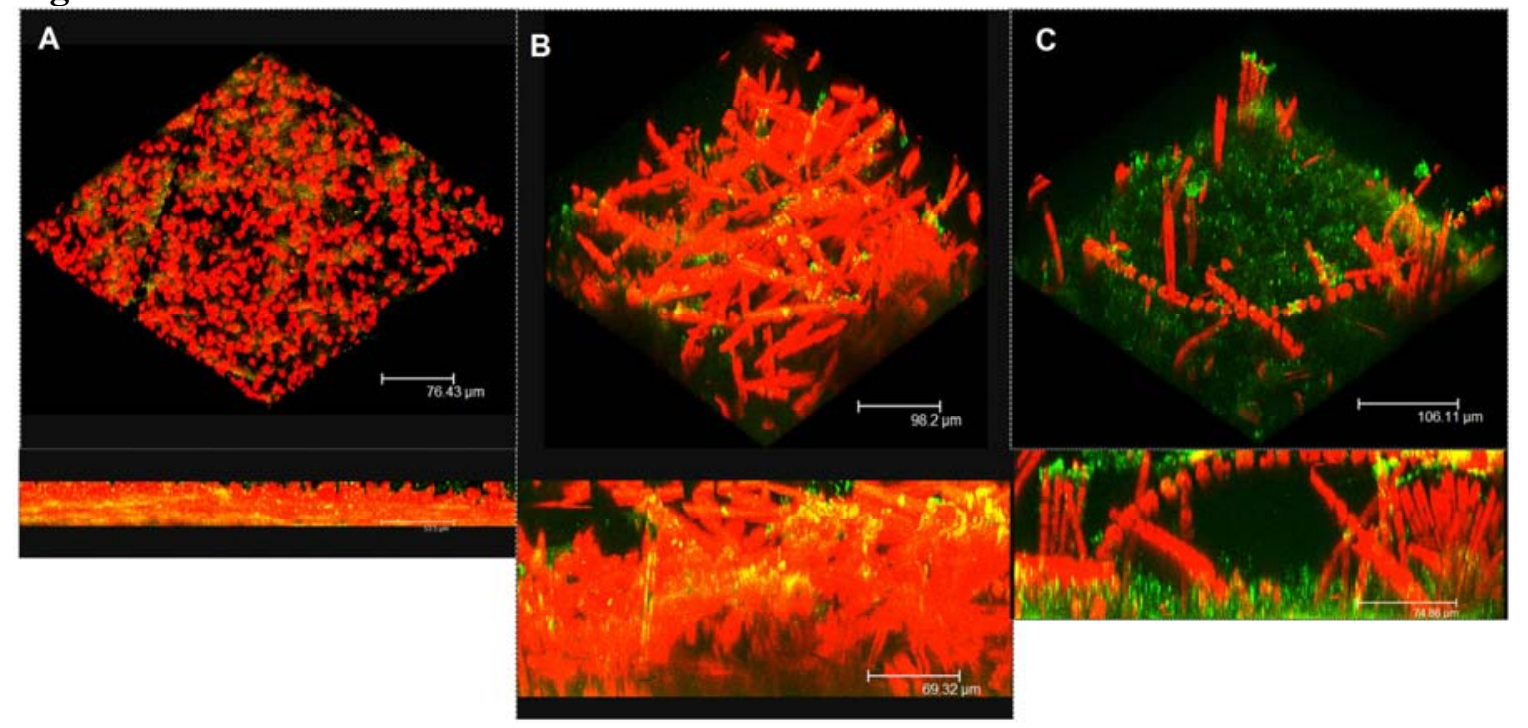


Figure 8.

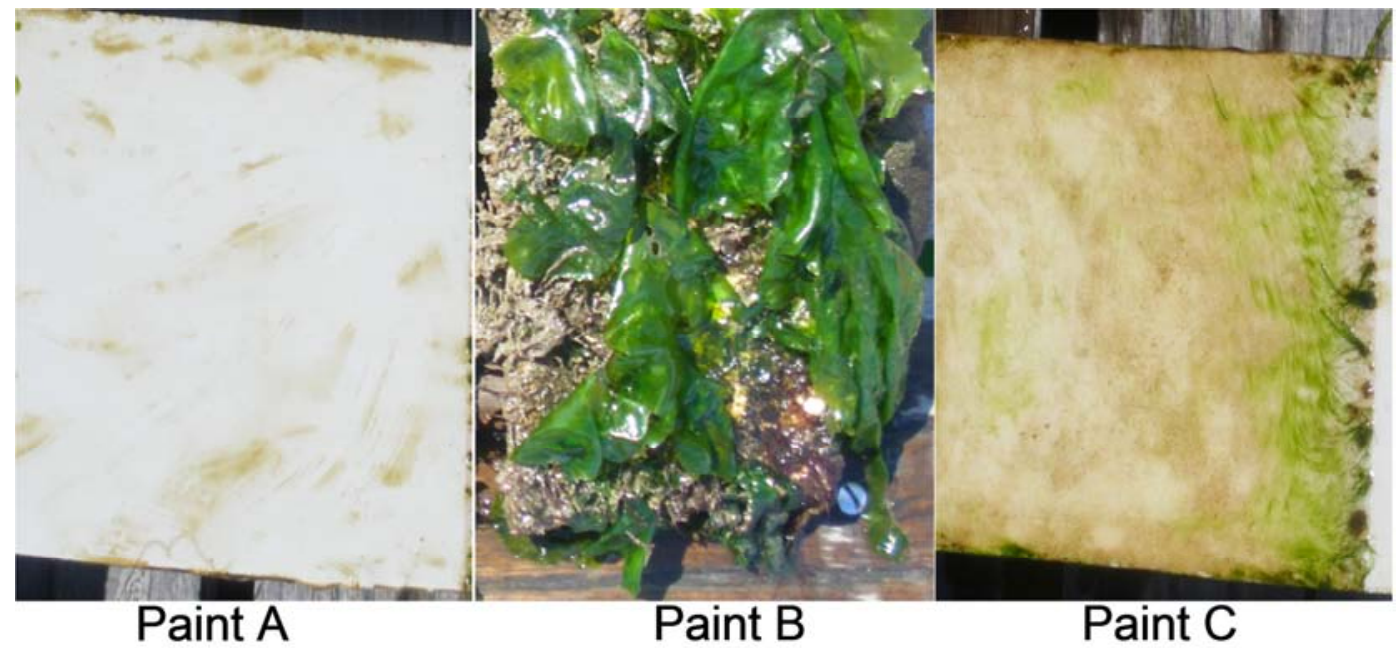


Table 1. Composition of paints (in wt $\%$ )

\begin{tabular}{lll}
\hline & Paint B & Paint C \\
\cline { 2 - 3 } & $\begin{array}{l}\text { Paint } \\
\text { without biocide }\end{array}$ & $\begin{array}{l}\text { P(CL-VL }) \\
\text { + active substances }\end{array}$ \\
\hline Xylene & 40 & 40 \\
Polyacrylic & 16.3 & - \\
$\mathrm{P}(\mathrm{CL}-\mathrm{VL})$ & - & 16.3 \\
Additives & 6 & 6 \\
BaSO & & - \\
TiO2 & 20.5 & 17.2 \\
Tween 85 & 17.2 & 6 \\
Chlorhexidine & - & 4.5 \\
Zinc peroxide $\left(\mathrm{ZnO}_{2}\right)$ & - & 10 \\
\hline
\end{tabular}


Table 2. Summary of $\mathrm{EC}_{50}$ and $\mathrm{EC}_{10}$ values for five marine organisms exposed to active substances and conventional biocides

\begin{tabular}{|c|c|c|c|c|c|c|}
\hline & $\mu g / L$ & $\begin{array}{l}\text { Phaedactylum } \\
\text { tricornutum }\end{array}$ & $\begin{array}{l}\text { Acartia } \\
\text { tonsa }\end{array}$ & $\begin{array}{l}\text { Crassostrea } \\
\text { gigas }\end{array}$ & $\begin{array}{l}\text { Paracentrotus } \\
\text { lividus }\end{array}$ & $\begin{array}{l}\text { Dicentrarchus } \\
\text { labrax }\end{array}$ \\
\hline \multirow{2}{*}{ Tween 85} & $\mathrm{EC}_{50}$ & $>1000$ & $>1,000$ & $>1,000$ & $>1,000$ & $>1000$ \\
\hline & $\mathrm{EC}_{10}$ & $>100$ & $100-1000$ & $1-10$ & $>1,000$ & $>1000$ \\
\hline \multirow{2}{*}{ Zinc peroxide } & $\mathrm{EC}_{50}$ & $>100$ & $>100$ & 59 & 1000 & $>1000$ \\
\hline & $\mathrm{EC}_{10}$ & $>100$ & $>100$ & 46.8 & 21.4 & 247 \\
\hline \multirow{2}{*}{ Chlorhexidine } & $\mathrm{EC}_{50}$ & 85 & $>1000$ & $>1000$ & 269.4 & $>1000$ \\
\hline & $\mathrm{EC}_{10}$ & 7.4 & $>1000$ & 10 & 0.1 & $>1000$ \\
\hline \multirow{2}{*}{$\begin{array}{l}\text { Copper } \\
\text { thiocyanate }\end{array}$} & $\overline{\mathrm{EC}_{50}}$ & 108 & 123 & 11 & 177 & 597 \\
\hline & $\mathrm{EC}_{10}$ & 9.5 & $10-100$ & 7.85 & 139 & 118 \\
\hline \multirow{2}{*}{ Dichlofluanid } & $\mathrm{EC}_{50}$ & 193 & $>1000$ & 131 & n.d & 15.6 \\
\hline & $\mathrm{EC}_{10}$ & 69.9 & 11.7 & 98.7 & n.d & 10.6 \\
\hline Zinc & $\mathrm{EC}_{50}$ & 7.43 & 9.15 & 11.1 & n.d & 144 \\
\hline pyrithione & $\mathrm{EC}_{10}$ & 0.59 & 0.98 & 7.3 & n.d & 95.6 \\
\hline
\end{tabular}


Table 3. Quantification of microfouling on antifouling paints after 5 weeks of immersion. Standard deviation in bracket

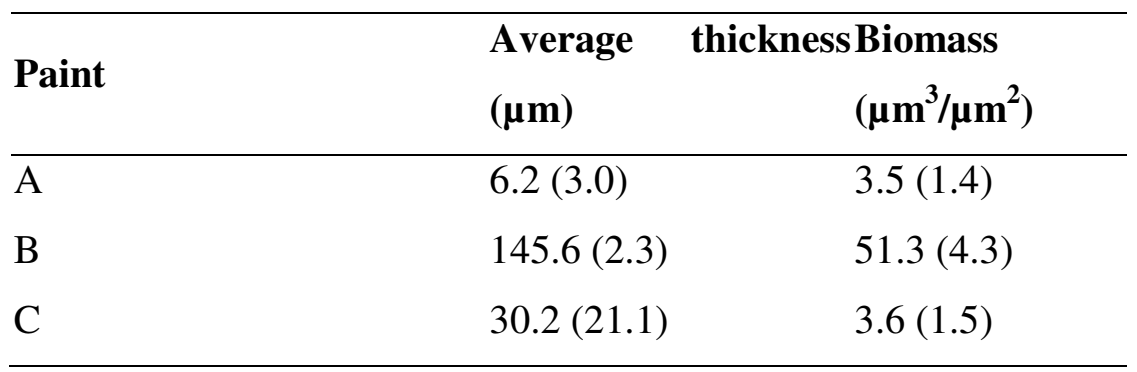

